\title{
Stability Analysis of Cut Slopes Using Continuous Slope Mass Rating and Kinematic Analysis in Rudraprayag District, Uttarakhand
}

\author{
R. K. Umrao, R. Singh, M. Ahmad, T. N. Singh \\ Department of Earth Sciences, Indian Institute of Technology Bombay Powai, Mumbai, India \\ E-mail: raviumrao@gmail.com \\ Received August 10, 2011; revised September 14, 2011; accepted September 25, 2011
}

\begin{abstract}
In mountain terrains of Himalaya, road and highway networks play a vital role in remote areas for transportation, public network and all kind of socio-economic activities. The stability of rock slopes along the roads and highways is a major concern in these hilly regions. Any kind of slope failure may lead to disruption in traffic, loss of properties and lives/injuries as well as environmental degradation. The unplanned excavations of rock slopes for construction or widening purposes may undermine the stability of the slopes. The present study incorporates the stability analysis of road cut slopes along NH-109 which goes to holy shrine of Kedarnath. Slope failure is not only a phenomenon of rainy season but it has also been encountered even in dry season. The study area experiences high vehicular traffic especially from March to August due to pilgrims since it is the only road to Kedarnath. The distance of about $20 \mathrm{~km}$ between Rudraprayag and Agastmuni has been investigated. The continuous slope mass rating (CSMR) technique has been used for slope stability analysis at five different locations. CSMR is modification of original slope mass rating (SMR) proposed by Romana which is based on well established rock mass rating (RMR) technique. Kinematic analysis was also carried out to evaluate these sites for types of failure and its potential failure directions. The potentially vulnerable sites were identified. The results indicate that the CSMR technique may be exploited to assess the stability of rock slopes in the Himalayan territory.
\end{abstract}

Keywords: SMR, CSMR, RMR, Slope Stability, Rudraprayag

\section{Introduction}

Slope failure has been identified as one of the most frequent natural disasters that can lead to huge loss of property and lives. The Lesser Himalaya region is tectonically active zone characterized by a very complex structure of thrust sheets [1]. Slope failures are triggered by number of external factors like tectonic forces, weathering and erosion processes, and compounded-anthropogenic factors in the high relief mountain system [2]. Over the years, human activity has significantly contributed to an increase in slope failures in the Himalaya because of expansion of road networks, settlements and other development activities. The analysis of landslides is much complex as number of factors contributes in it. So the analysis requires quite large number of input parameters and also the analytical techniques are costly and time consuming.
The road networks are only way of communication in mountain regions of Himalaya. The stability problem of rock slopes along roads in the Himalaya is a major concern in most of the places. There are lots of major as well as minor landslides reported in hilly areas especially in monsoon season due to heavy rainfall and also in postmonsoon season. These slides are not limited to monsoon season but also being encountered in dry season in minor scales $[3,4]$. The unplanned excavation of rock slopes for road construction and widening makes the slopes vulnerable. The vibrations induced due to blasting may cause widening of fractures. The exposed rock mass in Himalaya, which is already deformed, with steeper cut slopes along roads may prone to failure. The failure of slopes may lead to distraction in traffic. Several cases of distraction in traffic are being reported that may create lots of difficulties to travelers as well as pilgrims of holy shrines of Kedarnath and Badrinath. Therefore, evalua- 
tion of the stability situation along these roads and highways is imperative for safety and maintenance purposes.

There are several approaches of slope stability analysis are being used now days like limit equilibrium, analytical and kinematic, physical and numerical models [5-7]. One of the most widely used and adequate method is slope mass rating (SMR) technique $[8,9]$. SMR is based on the rock mass rating (RMR) technique given by Bieniawski $[10,11]$. RMR technique is based on detailed field and laboratory study which involves collection of data at site slopes, strength of rock exposed on slope face, condition of discontinuities, spacing of discontinuities, orientation of discontinuities, and ground water condition. SMR includes RMR along with some adjustment factors based on relation of joint orientation with slope and method of slope excavations. The adjustment factors in SMR technique, proposed by Romana, are discrete and are more decision based. The continuous SMR (CSMR) proposed by Tomas provides continuous determination and very less decision based [12-14]. The CSMR assigns unique value to each adjustment factor of slope that result into more accurate value of SMR [14].

The present study incorporates the assessment of road cut sections in Rudraprayag District, Uttarakhand, India. Field investigations have been carried out to study the lithological and structural variations in rock slopes between Rudraprayag and Agastmuni, about $20 \mathrm{~km}$ section along NH-109. Five locations were selected on the basis of exposures of the different lithology and the slope conditions. Slopes at these locations have been excavated by uncontrolled (or poor) blasting method for highway construction, were studied and analysed for their potential degree of stability using CSMR approach. Kinematic analysis has been performed for the line of intersection of two or more discontinuities, as the rocks are highly jointed in some parts of road cut sections. The kinematic analysis reveals the type and the possible direction of movement of failures along with identifying the potentially unfavourable joint planes.

\section{The Study Area}

The location of study area lies in Rudraprayag district, Uttarakhand, India. Rudraprayag is situated at the confluence of the Mandakini and the Alaknanda rivers, known in popular culture as the "Sangam". The town holds a prominent place as it is a stopover for the pilgrims and travelers to the world famous holy shrines of Badrinath and Kedarnath. From Rudraprayag, NH-109 and NH-58 split, the formers going towards Kedarnath and the latter towards Badrinath. The study area comes under NH-109 which runs from Rudraprayag to Kedarnath along Mandakini river (Figure 1). The study area between Rudra- prayag (N30 $17^{\prime} 6.30^{\prime \prime}$; E78 $\left.58^{\prime} 59^{\prime \prime}\right)$ and Agastmuni (N30 23'34.5"; E79 1'42.4”) comes under toposheet numbers $53 \mathrm{~J} / 15$ and $53 \mathrm{~N} / 3$ of the Survey of India toposheets.

\section{Geological Setting}

The study area comes in Garhwal group of lesser Himalaya and comprises diverse rock types ranging in age from Paleoproterozoic to Mesoproterozoic (Figure 2). The Main Central Thrust (MCT) and Almora Thrust mark the boundary of Garhwal group [15]. It consists of thick succession of low grade meta-sediments made up of quartzite along with penecontemporaneous metabasics and carbonate rocks. The Garhwal group has been divided into five formations as the Uttarkashi, Khattukhal, Rautgara, Deoban and Berinag formations in an ascending order. The rocks of Garhwal group were intruded by acid and basic igneous rocks [16]. The Garhwal group has been undergone three phases of tectonic deformations [15].

Mehdi et al. [17] and Kumar and Agrawal [15] were probably first to formulate the geology of the area. Negi et al. [18] have given the detailed report on geology and structure of Rudraprayag-Tilwara-Mayali area. The rock types exposed in the study area are Rudraprayag metavolcanics, Haryali quartzites, Tilwara quartzites, Tilwara metavolcaincs, epidiorites and Rampur chlorite phyllites. Rudraprayag metavolcanics are massive and jointed in rock mass with quartz, pyroxene, plagioclase, epidote as mineral constituents. Quartz veins as infilling along joints are exposed $1 \mathrm{Km}$ north from Rudraprayag.

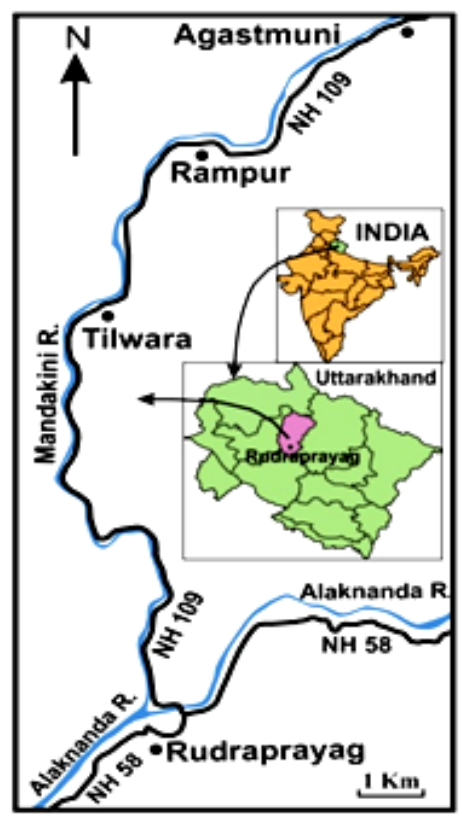

Figure 1. Location map of study area. 


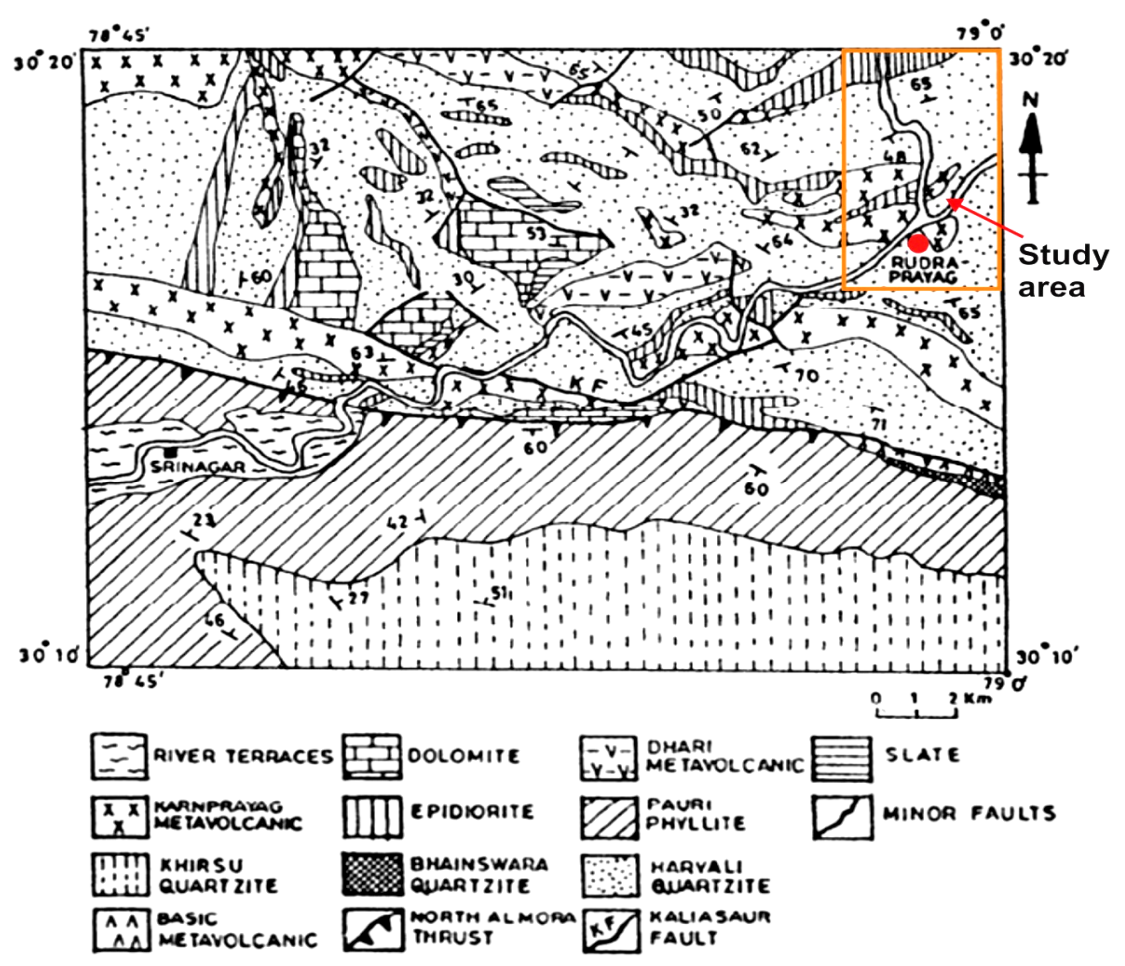

Figure 2. Geological map of the area (after Kumar and Agrawal [15]).

Haryali quartzite as named by Kumar and Agrawal [15] is very less metamorphosed, thick bedded, varying white to purple/pink in colour and well exposed between Rudraprayag and Tilwara. Along the joint planes, jasper, chert and talc occur as infilling material. Tilwara metavolcanics, light to very dark green in colour, are more metamorphosed and deformed than the Rudraprayag metavolcanics. It is mainly composed of feldspar and pyroxene which are altered. Tilwara quartzites are different than Rudraprayag/Haryali quartzite as are thin bedded, highly deformed and metamorphosed. In the east of Tilwara, the quartzites are metamo- rphosed into talc-quartzites and towards Rampur, the Tilwara quartzites are mainly of schistose type. The most of the formations of the study area have been intruded by sills and dykes of dolerite which have later been metamorphosed into epidiorite. Hornblende and plagioclase are the major mineral constituents with hornblende altering into chlorite and biotite, ilmenite, epidote as minor constituents. The light to dark green colour friable chlorite phyllite/ schist is best exposed on the right flank of the Mandakini River near Rampur.

\section{Method}

Field investigations have been carried out to study the attitude of excavated slopes and measurements of discontinuities present in the rock mass accompanied by collec- tion of representative samples. Laboratory experiments have been performed to evaluate the strength parameters as per ISRM suggested methods [19,20]. The continuous SMR (CSMR) technique has been used to classify the rock slopes at five different locations. CSMR is modification of discrete SMR technique of Romana which is based on Bieniawski's RMR technique. The SMR system provides adjustment factors, field guidelines and recommendations on support methods which allow a systematic use of geomechanical classification for slopes. The CSMR provides unique value of each adjustment factor unlike a range as in SMR.

RMR is computed according to Bieniawski's [10] proposal, adding rating values for five parameters: i) Strength of intact rock, ii) RQD (measured or estimated), iii) Spacing of discontinuities, iv) Condition of discontinuities, and v) Water inflow through discontinuities. RMR has a total range of 0 - 100 (Table 1).

The slope mass rating (SMR) proposed by Romana [8] is obtained from RMR by subtracting a factorial adjustment factor depending on the joint-slope relationship and adding a factor depending on the method of excavation

$$
\mathrm{SMR}=\mathrm{RMR}-\left(F_{1} \cdot F_{2} \cdot F_{3}\right)+F_{4}
$$

The CSMR is also computed using an equation which is similar to discrete SMR, but the difference lies in calculating the adjustment factors $\left(F_{1}, F_{2}\right.$ and $\left.F_{3}\right)$ which are depending on the joint-slope relationship. The factor $F_{4}$, 
Table 1. Rock mass classification (after Bieniawski [10]).

\begin{tabular}{|c|c|c|c|c|c|c|c|c|}
\hline \multirow{3}{*}{$\begin{array}{c}\text { Parameter } \\
\text { UCS }\end{array}$} & \multicolumn{8}{|c|}{ Ranges of Values } \\
\hline & Values & $>250 \mathrm{MPa}$ & $100-200 \mathrm{MPa}$ & $50-100 \mathrm{MPa}$ & $25-50 \mathrm{MPa}$ & $5-25$ & $1-5$ & $<1 \mathrm{MPa}$ \\
\hline & Rating & 15 & 12 & 7 & 4 & 2 & 1 & 0 \\
\hline \multirow{2}{*}{ RQD } & Values & $90-100 \%$ & $75-90 \%$ & $50-75 \%$ & $25-50 \%$ & \multicolumn{3}{|c|}{$25 \%$} \\
\hline & Rating & 20 & 17 & 13 & 8 & \multicolumn{3}{|c|}{3} \\
\hline \multirow{2}{*}{ Joint Spacing } & Values & $>2 \mathrm{~m}$ & $0.6-2.0 \mathrm{~m}$ & $200-600 \mathrm{~mm}$ & $60-200 \mathrm{~mm}$ & \multicolumn{3}{|c|}{$<60 \mathrm{~mm}$} \\
\hline & Rating & 20 & 15 & 10 & 8 & \multicolumn{3}{|c|}{5} \\
\hline \multirow[t]{2}{*}{ Joint Condition } & Values & $\begin{array}{l}\text { Very rough surfaces } \\
\text { No continuous } \\
\text { No separation } \\
\text { Unweathered wall }\end{array}$ & $\begin{array}{c}\text { Slightly rough surfaces. } \\
\text { Separation }<1 \mathrm{~mm} \\
\text { Slightly } \\
\text { weathered wall }\end{array}$ & $\begin{array}{c}\text { Slightly rough surfaces. } \\
\text { Separation }<1 \mathrm{~mm} . \\
\text { Highly } \\
\text { weathered wall }\end{array}$ & $\begin{array}{l}\text { Slickensided surfaces } \\
\text { OR gauge }<5 \mathrm{~mm} \text { thick } \\
\text { OR separation } 1-5 \mathrm{~mm}\end{array}$ & \multicolumn{3}{|c|}{$\begin{array}{l}\text { Soft gauge }>5 \mathrm{~mm} \\
\text { OR } \\
\text { Separation }>5 \mathrm{~mm} \\
\text { Continous }\end{array}$} \\
\hline & Rating & 30 & 25 & 25 & 25 & \multicolumn{3}{|c|}{0} \\
\hline \multirow{2}{*}{ Groundwater } & & Completely dry & Damp & Wet & Dripping & \multicolumn{3}{|c|}{ Flowing } \\
\hline & Rating & 15 & 10 & 7 & 4 & \multicolumn{3}{|c|}{0} \\
\hline
\end{tabular}

depending on the method of excavation is same for discrete SMR as well as CSMR.

The adjustment rating for discrete SMR is the product of three factors proposed by Romana [8] as follows:

(i) $F_{1}$ depends on parallelism between joints and slope face. Its range is from 1.00 to 0.15 . These values were empirically established by the following relationship

$$
F_{1}=(1-\sin A)^{2}
$$

where $A$ is angle between the dip directions of slope face and joint in case of planer and toppling failure. For wedge failure, $A$ is the angle between plunge direction of line of intersection formed by discontinuities and slope dip direction [21].

(ii) $F_{2}$ refers to joint dip angle in the planar mode of failure. In a sense, it is a measure of the probability of joint shear strength. Its value ranges from 1.00 to 0.15 . The empirically established by the following relationship

$$
F_{2}=\tan ^{2} B
$$

where $B$ is dip angle of joint for planer failure. In the wedge case, $B$ is dip angle of plunge of line of intersection [21]. For the toppling mode of failure $F_{2}$ remains 1.00 .

(iii) $F_{3}$ indicates the relationship between the slope face and joint dip. In the planar mode of failure, $F_{3}$ refers to the probability of joints day-lighted in the slope face. In case of wedge failure, $F_{3}$ indicates the relationship between the slope face and dip of plunge of intersection of two joints [21]. Conditions are favorable when slope face and joints are parallel and very unfavorable when the slope dips $10^{\circ}$ more than joints.

The adjustment factors $F_{1}, F_{2}$ and $F_{3}$ for CSMR, depends on joint-slope relationship, are calculated by using following equations proposed by Tomas et al. [12-14].

$$
F_{1}=\frac{16}{25}-\frac{3}{500} \arctan \left(\frac{1}{10}(|A|-17)\right)
$$

where, $F_{1}=$ adjustment factor,

$|\mathrm{A}|=|\alpha \mathrm{j}-\alpha \mathrm{s}|$ for planer failure,

$|\alpha \mathrm{i}-\alpha \mathrm{s}|$ for wedge failure,

$|\alpha j-\alpha s-180|$ for toppling failure, and

$\alpha j, \alpha s$ and $\alpha \mathrm{i}$ are dip direction of joint, slope and plunge direction of line intersection of two joint planes.

$$
F_{2}=\frac{9}{16}+\frac{1}{195} \arctan \left(\frac{17}{100} B-5\right)
$$

where $B$ is equals to dip $(\beta j)$ of joint for planer failure and topping, to dip on plunge of line of intersection for wedge failure.

$$
\begin{gathered}
F_{3}=-30+\frac{1}{3} \arctan (C) \\
F_{3}=-13-\frac{1}{7} \arctan (C-120)
\end{gathered}
$$

where, $C$ is an angular difference of dips of joint and slope $(\beta \mathrm{j}-\beta \mathrm{s})$ for planer failure. $C$ is difference of dip of plunge of line and dip of slope $(\beta \mathrm{i}-\beta \mathrm{s})$ for wedge. For topping, $C$ is defined as sum of dip of joint and slope $(\beta \mathrm{j}+\beta \mathrm{s})$.

The adjustment factor for the method of excavation (F4) has been fixed empirically as follows:

Natural slopes: $F_{4}=+15$, Presplitting: $F_{4}=+10$,

Smooth blasting: $F_{4}=+8$, Normal blasting: $F_{4}=0$,

Deficient blasting: $F_{4}=-8$, and

Mechanical excavation: $F_{4}=0$.

The stability classes of SMR values, rock mass description, stability and probability of failure given by Romana [8] is also applicable for CSMR classification (Table 2). 


\section{Results and Discussion}

Detailed geological investigations including structural mapping were made in the study area at RudraprayagAgastmuni road section along NH-109. The road cut sections of varying slope height constitute the best outcrops for determining the lithological variations, weathering conditions, and structural geological characteristics of the outcrops and rock excavation to record discontinuities and joint patterns (Figure 3). The study comprised of investigation of slopes at five locations which have different lithological as well as geotechnical characteristics.

The cut slopes have steep to very steep dip angle with a developed system of joints (Table 3). In general, the rock mass has been covered by soil of quaternary age with scanty vegetation. Kinematic analysis indicates mainly wedge type of failure along with few toppling and planar based on the joint patterns (Figure 4). The joint forming planar type is not day-lighted (Figure 4(a)). The critical zone of failure has been shown in pink colour in stereographic projection for all five locations (Figure 4).

Table 2. Stability classes as per SMR values (Romana [8]).

\begin{tabular}{|c|c|c|c|c|c|}
\hline Class & I & II & III & IV & V \\
\hline SMR & $81-100$ & $61-80$ & $41-60$ & $21-40$ & $0-20$ \\
\hline $\begin{array}{l}\text { Rock mass } \\
\text { Description }\end{array}$ & Very good & Good & Normal & $\mathrm{Bad}$ & Very bad \\
\hline Stability & Completely stable & Stable & Partially stable & Unstable & Completely unstable \\
\hline Failures & None & Some block failure & $\begin{array}{c}\text { Planar along some joints } \\
\text { or many wedge failure }\end{array}$ & Planar or big wedge failure & $\begin{array}{c}\text { Big planar or soil-like or } \\
\text { circular }\end{array}$ \\
\hline $\begin{array}{c}\text { Probability } \\
\text { of } \\
\text { Failure }\end{array}$ & 0.9 & 0.6 & 0.4 & 0.2 & 0 \\
\hline
\end{tabular}

Table 3. Joints data of different locations.

\begin{tabular}{|c|c|c|c|c|c|c|c|c|}
\hline & \multirow{2}{*}{ Rock type } & \multirow{2}{*}{ Orientation of slope } & \multicolumn{6}{|c|}{ Orientation of joints } \\
\hline & & & $\mathrm{J} 1$ & $\mathrm{~J} 2$ & $\mathrm{~J} 3$ & $\mathrm{~J} 4$ & J5 & J6 \\
\hline L1 & Epidiorite & $70^{\circ} / 315^{\circ}$ & $80^{\circ} / 0^{\circ}$ & $80^{\circ} / 315^{\circ}$ & $70^{\circ} / 60^{\circ}$ & $65^{\circ} / 255^{\circ}$ & $85^{\circ} / 260^{\circ}$ & $45^{\circ} / 150^{\circ}$ \\
\hline $\mathrm{L} 2$ & Tilwara quartzite & $75^{\circ} / 267^{\circ}$ & $47^{\circ} / 80^{\circ}$ & $52^{\circ} / 226^{\circ}$ & $80^{\circ} / 60^{\circ}$ & $70^{\circ} / 160^{\circ}$ & $30^{\circ} / 10^{\circ}$ & - \\
\hline L3 & Phyllite & $70^{\circ} / 318^{\circ}$ & $81^{\circ} / 80^{\circ}$ & $70^{\circ} / 200^{\circ}$ & $75^{\circ} / 5^{\circ}$ & $45^{\circ} / 40^{\circ}$ & $47^{\circ} / 16^{\circ *}$ & - \\
\hline L4 & Rudraprayag quartzite & $80^{\circ} / 180^{\circ}$ & $30^{\circ} / 315^{\circ}$ & $52^{\circ} / 155^{\circ}$ & $56^{\circ} / 65^{\circ}$ & - & - & - \\
\hline L5 & Rudraprayag metavolcanics & $70^{\circ} / 282^{\circ}$ & $85^{\circ} / 30^{\circ}$ & $70^{\circ} / 150^{\circ}$ & $50^{\circ} / 250^{\circ}$ & - & - & - \\
\hline
\end{tabular}

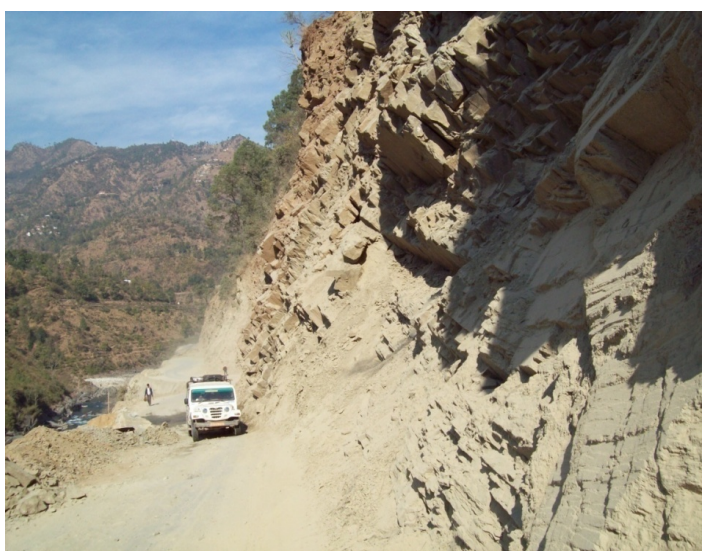

Figure 3. A cut slope section of the study area showing negative slope with 3 sets of joint.
Rock mass rating (RMR) has been calculated by five parameters namely uniaxial compressive strength (UCS), rock quality designation (RQD), spacing of discontinuities, conditions of discontinuities and ground water condition. UCS has been calculated by laboratory experiments in universal testing machine (UTM). The mean values of UCS have been used in calculation. RQD has been calculated from the relation between RQD and joint volume count $\left(\mathrm{J}_{\mathrm{V}}\right)$ [22]. The results of required parameters for RMR classification have been given in Table 4 . The calculation of RMR has been performed for all five locations (Table 5). As per the standard classification, RMR value at L1 and L4 which has rating of 71 can be classified as good rock. RMR value at L2 which has rating value of 57 can be classified as fair rock. The rock 

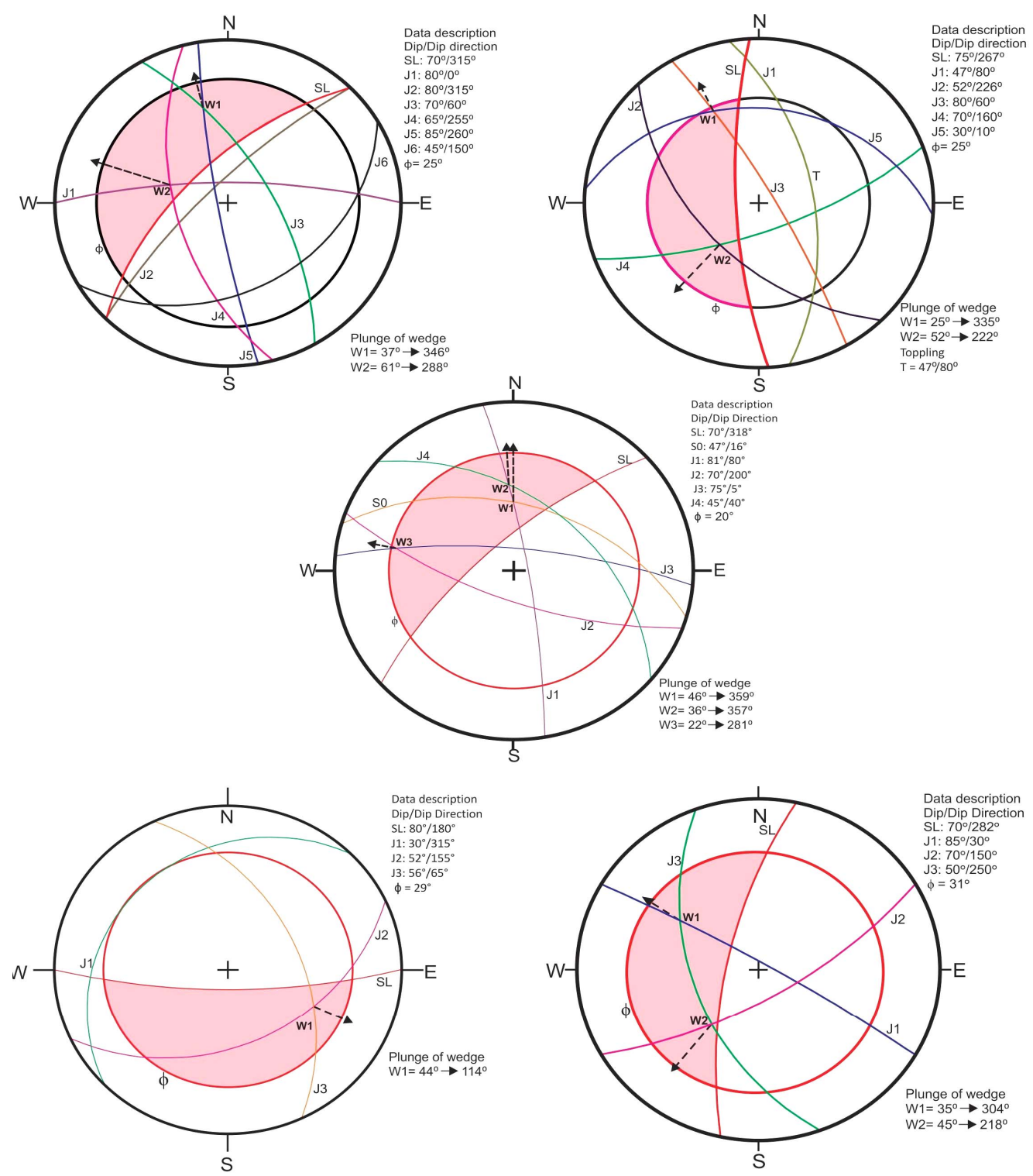

Figure 4. Plot of joints and slope at locations L1, L2, L3, L4 and L5. The pink coloured area indicates the critical zone of failure. The symbols used in figure are as SL: Slope; S0: Bedding, J1, J2, J3, J4, J5, and J6: Orientation of joints; W1, W2 and W3: Wedge formed by intersection of joints; T: Toppling.

mass with rating value of 42 may be classified as fair rock but as it is very close to the boundary between fair and poor rock so it requires special attention as well as proper care of slope. The rock mass at L5 with rating value of 82 may be classified as very good rock.

CSMR has been calculated from equation (1) using RMR values for all five locations (Table 5). The adjustment factors $F_{1}, F_{2}$ and $F_{3}$, based on joint-slope relationship, have been calculated from the formulae proposed by Tomas et al. [12-14]. The orientation of discontinuities with respect to slope forming wedge, toppling and planar type of failure in critical zone of influence as in kinematic analysis plots (Figure 5). In case the two discontinuity intersecting and forming wedge in critical zone, the orientation of plunge of intersections of two discontinuities has been calculated. The wedge type of failure is common in all locations. The rock slope is being excavated using drilling and blasting technique. The uncontrolled blasting and drilling operation for excavations of slope lead to the failure of large size blocks (Figure 6). Blast-induced vibrations expand the zone of influence for failures replicating a controlled earthquake, affecting the stability of slope. The adjustment factor for method of excavation $\left(F_{4}\right)$ is considered as deficient blasting. 
Table 4. Result of geological observations required for rock mass rating (RMR).

\begin{tabular}{cccccc}
\hline Parameter & L1 & L2 & L3 & L4 & L5 \\
\hline Rock type & Epidiorite & Tilwara quartzite & Phyllite & Rudraprayag quartzite & Rudraprayag metavolcanics \\
Mean UCS & $58 \mathrm{MPa}$ & $40 \mathrm{MPa}$ & $28 \mathrm{MPa}$ & $54 \mathrm{MPa}$ & $123 \mathrm{MPa}$ \\
RQD (calculated from JV)* & $85 \%$ & $65 \%$ & $49 \%$ & $80 \%$ & $92 \%$ \\
Joint spacing & $20 \mathrm{~cm}-60 \mathrm{~cm}$ & $20 \mathrm{~cm}-6 \mathrm{~cm}$ & $<60 \mathrm{~mm}$ & $20 \mathrm{~cm}-6 \mathrm{~cm}$ & $>2 \mathrm{~m}$ \\
Joint roughness & Rough & Rough & Smooth & Slightly rough & Rough \\
Joint separation & $0.1-1 \mathrm{~mm}$ & $1-5 \mathrm{~mm}$ & $1-5 \mathrm{~mm}$ & $0.1-1 \mathrm{~mm}$ & $1-5 \mathrm{~mm}$ \\
Joint persistence & $3-10 \mathrm{~m}$ & $1-3 \mathrm{~m}$ & $10-20 \mathrm{~m}$ & $1-3 \mathrm{~m}$ & $3-10 \mathrm{~m}$ \\
Joint infilling & None & Soft filling $>5 \mathrm{~mm}$ & Hardfilling $>5 \mathrm{~mm}$ & None & None \\
Weathering & Slightly weathered & Moderately weathered & Slightly weathered & Slightly weathered & Unweathered \\
Ground water condition & Dry & Dry & Dry & Dry & Dry \\
\hline
\end{tabular}

Table 5. Rock Mass Rating (RMR) at different locations.

\begin{tabular}{|c|c|c|c|c|c|}
\hline Parameter & L1 & L2 & L3 & L4 & L5 \\
\hline Rock type & Epidiorite & Tilwara quartzite & Phyllite & Rudraprayag quartzite & $\begin{array}{l}\text { Rudraprayag metavol- } \\
\text { canics }\end{array}$ \\
\hline UCS Rating & 7 & 4 & 4 & 7 & 12 \\
\hline RQD Rating & 17 & 13 & 8 & 17 & 20 \\
\hline Joint spacing Rating & 10 & 8 & 5 & 10 & 15 \\
\hline Joint condition Rating* & $\begin{aligned} 2+4 & +5+6+5 \\
& =22\end{aligned}$ & $\begin{array}{c}4+1+5+4+3 \\
=17\end{array}$ & $\begin{aligned} 1+1 & +1+2+5 \\
& =10\end{aligned}$ & $\begin{aligned} 4+4 & +3+6+5 \\
& =22\end{aligned}$ & $\begin{aligned} 2+4 & +5+6+6 \\
& =23\end{aligned}$ \\
\hline Ground water Rating & 15 & 15 & 15 & 15 & 15 \\
\hline RMR & 71 & 57 & 42 & 71 & 85 \\
\hline
\end{tabular}

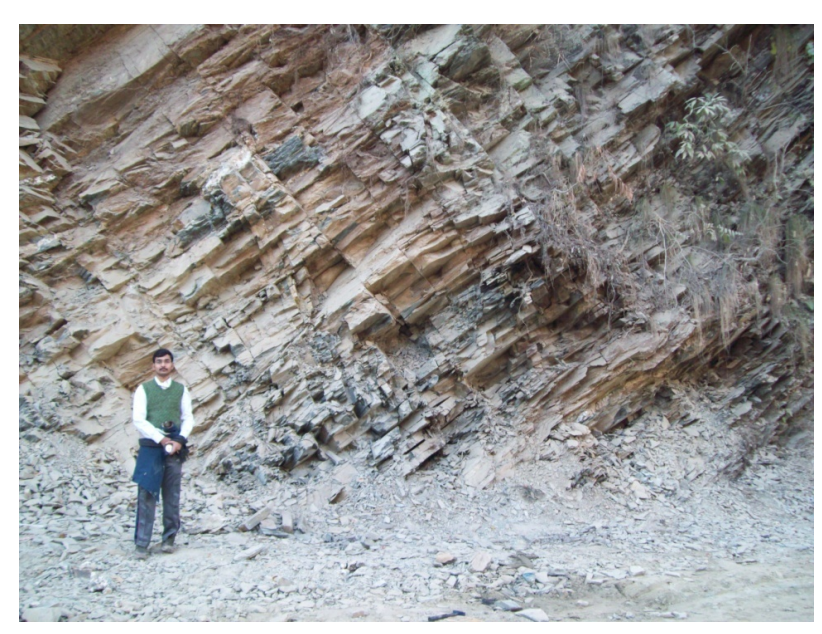

Figure 5. Very closed space jointed phyllitic rock with higher persistency.

The influence of orientation of joints and method of excavation of slopes has been applied for final modification of the rock mass rating value. The continuous slope mass rating (CSMR) has been calculated for wedge and

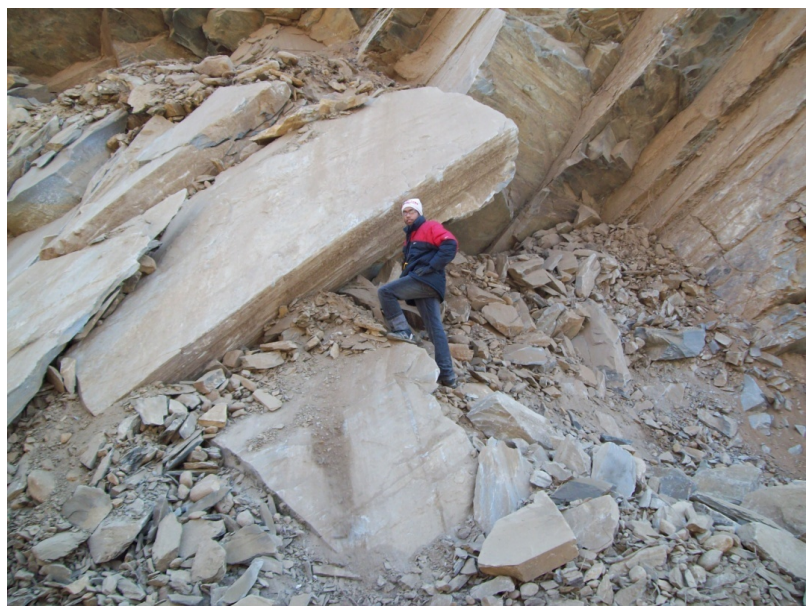

Figure 6. Large size rock blocks failure due to blasting.

toppling failures for all five locations (Table 6). As per the standard classification, the values of CSMR at L1 (Epidiorite rock) shows values 47 and 42 for $\mathrm{W} 1$ and $\mathrm{W} 2$ respectively. The slope may be classified in class III as partially stable. At location L2, Tilwara quartzite rock 
Table 6. Results of continuous slope mass rating (CSMR).

\begin{tabular}{|c|c|c|c|c|c|c|c|c|c|c|c|}
\hline & RMR & Slope orientation & Feature & Dip & Dip direction & $\mathrm{F} 1$ & $\mathrm{~F} 2$ & F3 & F4 & CSMR & Class/ Stability \\
\hline \multirow{2}{*}{ L1 } & \multirow{2}{*}{71} & \multirow{2}{*}{$70^{\circ} / 315^{\circ}$} & W1 & $37^{\circ}$ & $346^{\circ}$ & 0.31 & 0.83 & 59.42 & \multirow{2}{*}{-8} & 47.55 & III/ Partially stable \\
\hline & & & $\mathrm{W} 2$ & $61^{\circ}$ & $288^{\circ}$ & 0.37 & 0.97 & 57.89 & & 42.23 & III/ Partially stable \\
\hline \multirow{3}{*}{ L2 } & \multirow{3}{*}{57} & \multirow{3}{*}{$75^{\circ} / 267^{\circ}$} & $\mathrm{T}$ & $47^{\circ}$ & $80^{\circ}$ & 0.91 & 0.93 & 22.06 & \multirow{3}{*}{-8} & 30.34 & IV/ Unstable \\
\hline & & & W1 & $25^{\circ}$ & $335^{\circ}$ & 0.17 & 0.37 & 59.62 & & 45.22 & III/ Partially stable \\
\hline & & & W2 & $52^{\circ}$ & $222^{\circ}$ & 0.22 & 0.95 & 59.17 & & 36.76 & IV/ Unstable \\
\hline \multirow{3}{*}{ L3 } & \multirow{3}{*}{42} & \multirow{3}{*}{$70^{\circ} / 318^{\circ}$} & $\mathrm{W} 1$ & $46^{\circ}$ & $359^{\circ}$ & 0.24 & 0.92 & 59.20 & \multirow{3}{*}{-8} & 21.11 & IV/ Unstable \\
\hline & & & $\mathrm{W} 2$ & $36^{\circ}$ & $357^{\circ}$ & 0.25 & 0.81 & 59.44 & & 22.13 & IV/ Unstable \\
\hline & & & W3 & $22^{\circ}$ & $281^{\circ}$ & 0.26 & 0.30 & 59.60 & & 29.39 & IV/ Unstable \\
\hline L4 & 71 & $80^{\circ} / 180^{\circ}$ & W1 & $44^{\circ}$ & $114^{\circ}$ & 0.27 & 0.91 & 59.47 & -8 & 48.55 & III/ Partially stable \\
\hline \multirow{2}{*}{ L5 } & \multirow{2}{*}{85} & \multirow{2}{*}{$70^{\circ} / 282^{\circ}$} & $\mathrm{W} 1$ & $35^{\circ}$ & $304^{\circ}$ & 0.48 & 0.79 & 59.45 & \multirow{2}{*}{-8} & 54.55 & III/ Partially stable \\
\hline & & & W2 & $45^{\circ}$ & $218^{\circ}$ & 0.17 & 0.92 & 59.24 & & 67.64 & II/ Stable \\
\hline
\end{tabular}

with one toppling and two wedges (W1 and W2) having CSMR values 30,45 and 37 respectively. The slope is unstable in case of toppling and W2 but partially stable for W1.

During field investigations and petrographic study, it has been observed that Tilwara quartzites rock is more deformed and crushed grains in internal atomic arrangement that shows protomylonitic behavior under microscope. So it is considered in class IV. At L3, phyllite rock with three wedges with CSMR values 21, 22 and 29 respectively. The slope can be classified under class IV as unstable. At L4, Haryali quartzite with CSMR value 48 may be classified in class III as partially stable. At L5, Rudraprayag Metavolcanics with two wedge (W1 and W2) and CSMR values 51 and 65. Slope may be classified as partially stable for W1 and stable for W2. The observation from field indicating that slope at L5 is stable. The CSMR values obtained for all five locations have been plotted in CSMR class- Probability of failure chart based on Romana standard classification of SMR [8] (Figure 7).

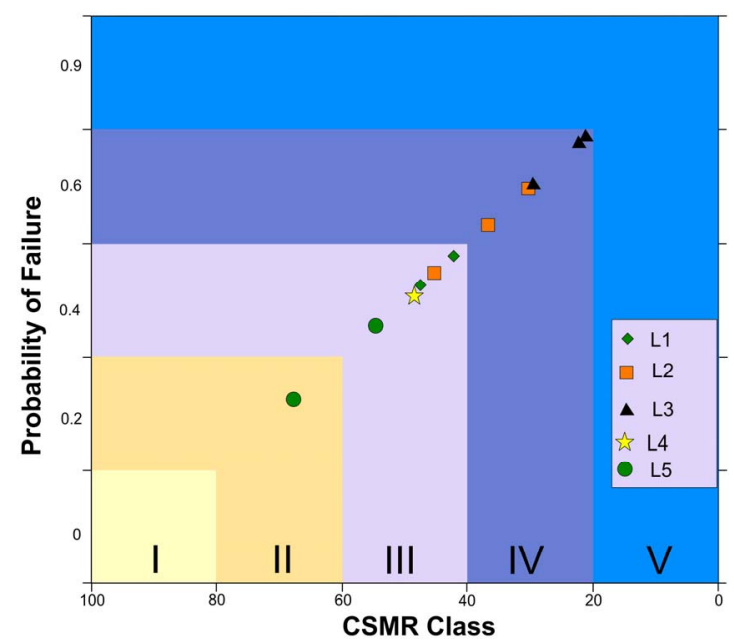

Figure 7. The plot of CSMR values of five different locations.

\section{Conclusions}

The rock mass classifications are very significant tool for characterization of rock mass especially for slope vulnerability assessment. The slope mass rating is the most comprehensive and widely used technique for rock slope assessment. The Continuous SMR system seems to be more sensitive to the slope characteristics and yields finer rating values than does the discrete SMR system. The five slopes have been studied in Himalayan region along NH-109 cut slopes and the values of CSMR indicate that phyllite and Tilwara quartzite slopes are more vulnerable as compared to Haryali quartzite and Epidiorite slopes. These slopes required immediate treatment to avoid any kind of mis-happening due to slope failure. Further, the results of continuous slope mass rating is closely matching with the field observations. This technique may be helpful for rapid investigation of slopes in deformed hilly terrains.

\section{Acknowledgements}

The authors express their sincere acknowledgement to the Department of Science and Technology for the grant and support.

\section{References}

[1] G. Kumar, "Geology and Sulphide Mineralization the Pokheri Area Chamoli District, Uttar Pradesh," Geological Survey of India Miscelleneous Publication, Vol. 16, 1971, pp. 92-128.

[2] N. S. Virdi, M. P. Sah and S. K. Bartarya, "Project Report: Landslide Hazard Zonation in the Beas and Satluj Valleys of Himanchal Pradesh, Phase-I Satluj Valley," Wadia Institute of Himalayan Geology Technical Report, Volume unpublished, 1995, p. 132.

[3] P. Rautela and R. K. Pande, "Traditional Inputs in Disaster Management: The Case of Amparav, North India," 
International Journal of Environmental Studies, Vol. 62, No. 5, 2005, pp. 505-515.

http://dx.doi.org/10.1080/00207230500034586

[4] A. Uniyal and R. K. Pande, "The Fury of Nature in Uttaranchal: Uttarkashi Landslide of the Year 2003," Disaster Prevention and Management, Vol. 16, No. 4, 2007, pp. 562-575. http://dx.doi.org/10.1108/09653560710817048

[5] R. Anbalagan, S. Sharma and T. K. Raghuvanshi, "Rock Mass Stability Evaluation Using Modified SMR Approach," Proceedings 6th Natural Symposium on Rock Mechanics, Bangalore, India, 1992, pp. 258-268.

[6] V. Vishal, S. P. Pradhan, and T. N. Singh, "Instability Assessment of Mine slope-A finite element approach," International Journal of Earth Sciences \& Engineering, Vol. 3, No. 6, 2010, pp. 11-23.

[7] S. P. Pradhan, V. Vishal, and T. N. Singh, "Slope Mass Rating for Evaluation of Health of Slopes in an Open Cast Mine in Jharia Coalfield India," Mining Engineers' Journal, Vol. 12, No. 10, 2011, pp. 36-40.

[8] M. Romana, "New Adjustment Ratings for Application of Bieniawski Classification to Slopes," Proceedings of International Symposium on the Role of Rock Mechanics, International Society for Rock Mechanics, Salzburg, 1985, pp. 49-53.

[9] M. Romana, "A Geomechanical Classification for Slopes: Slope Mass Rating," In: J. A. Hudson Ed., Comprehesive Rock Engineerin, Pergamon Press, Oxford, 1993, pp. 575-600.

[10] Z. T. Bieniawski, "The Geomechanical Classification in Rock Engineering Applications," Proceedings of 4th International Congress on Rock Mechanics, International Society for Rock Mechanics, Salzburg, Vol. 2, 1979, pp. 41-48.

[11] Z. T. Bieniawski, "Engineering Rock Mass Classification," Chichester, Wiley, London, 1989.

[12] R. Tomas, A. Cuenca and J. Delgado, "Modificación del Slope Mass Rating (SMR) a través de Funciones Continuas," Ingeniería Civil, Vol. 134, 2004, pp. 17-24.

[13] R. Tomas, M. Cano, A. Cuenca, J. C. Canaveras and J.
Delgado, "Nuevas Funciones Continuas para el Calculo del Slope Mass Rating," Rev Soc Geol Espana, Vol. 19, 2006, pp. 87-97.

[14] R. Tomas, J. Delgadob and J. B. Seron, "Modification of Slope Mass Rating (SMR) by Continuous Functions," International Journal of Rock Mechanics \& Mining Sciences, Vol. 44, No. 7, 2007, pp. 1062-1069.

[15] G. Kumar and N. C. Agrawal, "Geology of the Srinagar-Nandprayag Area (Alakananda Valley), Chamoli, Garhwal and Tehri Garhwal Districts, Kumaun Himalaya, Uttar Pradesh," Himalayan Geology, Vol. 5, 1975, pp. 29-59.

[16] G. Kumar, "Geology of Uttar Pradesh and Uttaranchal," Geological Society of India, Banglore, 2005, p. 383.

[17] S. H. Mehdi, G. Kumar and G. Prakash, "Tectonic Evolution of Eastern Kumaon Himalaya: A New Approach," Himalayan Geology, Vol. 2, 1972, pp. 481-501.

[18] S. S. Negi, A. K. Sinha and B. K. Pandey, "A Preliminary Report on the Geology and Structure of the RudraprayagTilwara-Mayali Area of Garhwal Himalaya," Himalayan Geology, Vol. 10, 1980, pp. 211-219.

[19] International Society of Rock Mechanics, "Suggested Methods for Determining Tensile Strength of Rock Materials," International Journal of Rock Mechanics and Mining Sciences, Geomechanics Abstract, Vol. 15, No. 3, 1978, pp. 99-103. http://dx.doi.org/10.1016/0148-9062(78)90003-7

[20] International Society of Rock Mechanics, "Rock Characterization Testing and Monitoring, ISRM Suggested Methods," Salzburg, 1981, p. 211.

[21] B. Singh and R. K. Geol, "Rock Mass Classification: A Practical Approach in Civil Engineering," Elsevier, Amsterdam, 1999, p. 282.

[22] A. Palmstrom, "The Volumetric Joint Count-a Useful and Simple Measure of the Degree of Rock Mass Jointing," Proceedings of 4th Conference of International Association of Engineering Geologist, New Delhi, 1982, pp. 221-228. 